\title{
MENINGKATKAN KETERAMPILAN MEMPERKENALKAN DIRI ANAK BORDERLINE MELALUI MODELLING
}

\section{MODELING TECHNIQUE TO IMPROVE SELF INTRODUCING SKILL IN BORDERLINE CHILDREN}

\author{
Niken Fahma Prahesti \\ Diana Savitri Hidayati \\ Fakultas Psikologi, Universitas Muhammadiyah Malang \\ Email: dhi2savitri@yahoo.co.id
}

\begin{abstract}
Borderline is a developmental disorder, characterized the intelligence value of 69-79, is less capable of socializing, communication, self-care and low academic functioning. Introducing ourself is one of the aspects of social skills. Modelling is used as an activity to observe and imitate the most preferred by children, so that the material is taught with a faster observation practiced by children. Video modeling and instruction was used repeatedly in this study. The research aims to find out whether Modelling can improve the skills introduced himself Borderline child. Explanatory research using experimental designs with design One - Group Pretest - Posttest Design. Sample study conducted by purposive sampling with the number 5 grade 5 SDLB Ruhui Rahayu deviation Samarinda with 10-15 years of age and have a value of intelligence quotient (IQ) 69-79. Documentation of data collection methods, observation, interviews and scales introduce myself. Methods of data analysis using the comparative value of pretest and posttest. The results showed no change in the value of introducing themselves before and after treatment in the form of modeling. . It is seen from the difference in the value of the pretest and posttest mean pretest 18.07 value increased to 30.80 at posttest with comparison $(p=0486)$ and there was no difference in the assessment carried out by teachers and researchers $(p=0.000)$.
\end{abstract}

Key words : Borderline, modelling

\begin{abstract}
ABSTRAK
Penelitian bertujuan mengetahui apakah Modelling dapat meningkatkan keterampilan memperkenalkan diri anak Borderline. Modelling dalam penelitian ini menggunakan video dan instruksi yang berulangulang. Penelitian menggunakan Eksplanasi eksperimen dengan rancangan desain One-Group PretestPosttest Design. Sampel penelitian dilakukan dengan purposive sampling dengan jumlah 5 orang siswa kelas 5 SDLB Ruhui Rahayu Samarinda dengan usia deviasi 10-15 tahun dan memiliki nilai intelegensi quotient (IQ) 69 - 79. Metode pengumpulan data dokumentasi, observasi, wawancara dan skala memperkenalkan diri. Metode analisa data menggunakan perbandingan nilai pretest dan posttest. Hasil penelitian menunjukan ada perubahan nilai memperkenalkan diri sebelum dan sesudah perlakuan berupa modeling. Hal ini dilihat dari perbedaan nilai pretest dan posttest dengan rata-rata nilai pretest 18.07 meningkat menjadi 30.80 pada saat posttest dengan perbandingan $(p=0.486)$ dan tidak ada perbedaan penilaian yang dilakukan oleh guru dan peneliti $(p=0,000)$.
\end{abstract}

Kata kunci : Keterampilan memperkenalkan diri, modeling 
Pendidikan merupakan usaha yang dilakukan oleh orang tua untuk mempersiapkan generasi yang akan datang. Proses pendidikan juga berlangsung dalam lingkungan keluarga, sekolah dan masyarakat. Orang tua merupakan pendidik yang pertama dan utama. Menurut Mulyadi, (Hamalik, 2010) pada dasarnya setiap orang tua mendambakan anak-anak yang cerdas dan berperilaku baik dalam kehidupan sehari-hari. Orang tua yang memiliki anak berkebutuhan khusus sangat mempercayakan anak mereka kepada lembaga pendidikan berkebutuhan khusus seperti sekolah luar biasa maupun yayasan yang menangani keperluan mereka.

Dalam dunia pendidikan khususnya di sekolah luar biasa, anak borderline disebut dengan anak tunagrahita ringan dan masuk dalam klasifikasi kelas C1 (Delphie, 2006). Adapun istilah lain dari tunagrahita adalah retardasi mental. Retardasi mental dibagi menjadi empat klasifikasi, yaitu retardasi mental ringan (mild), retardasi mental sedang (moderate), retardasi mental berat (severe) dan retardasi mental sangat berat (profound). Menurut nilai intelegensi dari hasil klasifikasi, borderline masuk dalam tingkat retardasi mental ringan (mild) dengan nilai intelegensi 69-79 (Azwar, 2012). Anak dengan tipe klasifikasi borderline, tergolong individu mampu didik, yang berarti masih bisa dilatih keterampilan tertentu untuk mampu mandiri seperti keterampilan sosial (Effendi, 2006).

Hallahan (Gabbe, 2008 ) mengestimasi jumlah penyandang borderline di Indonesia adalah 2,3\%. Borderline mengacu pada keterbatasan substansial dalam menampilkan fungsifungsi seseorang. Luckasson (Dephie, 2006) berpendapat bahwa Borderline memiliki fungsi intelektual perbatasan di bawah rata-rata, yang diikuti dengan keterbatasan dalam bidang keterampilan adaptasi, komunikasi, perawatan diri dan rumah tinggal, keterampilan sosial, kemampuan bermasyarakat, mengarahkan diri, keamanan dan harga diri, fungsi akademik, memanfaatkan waktu luang dan bekerja.

Sebagai makhluk individu dan sosial, individu borderline mempunyai hasrat untuk memenuhi segala kebutuhan sebagaimana layaknya anak normal lainnya, seperti mempunyai teman untuk bermain. Akan tetapi upaya individu tersebut mengalami hambatan karena anak borderline susah untuk mengawali sebuah percakapan agar bisa bersosialisasi dengan lingkungannya. Terlebih mereka sulit untuk memperkenalkan diri mereka kepada orang lain, sehingga anak borderline tidak mengerti tentang nama panjangnya, alamat rumah dan nama orang tua mereka.

Gumpel (1994) mengatakan bahwa perlunya keterampilan sosial adalah agar individu dapat menyesuaikan diri, karena 
adanya tuntutan yang bersifat internal maupun eksternal yang memaksa individu melakukan kontak sosial di lingkungan. Adanya hambatan dalam perkembangan sosialisasinya mengakibatkan individu borderline memiliki kecenderungan menyendiri serta memiliki sifat egosentris. Utami (Siboro, 2007) berpendapat bahwa pentingnya keterampilan sosial bagi perkembangan anak adalah anak dapat berperilaku dan berinteraksi dengan orang lain sesuai dengan konteks sosialnya. Dengan keterampilan sosial yang dimiliki, maka anak mampu dan terampil dalam menciptakan, membangun dan mempertahankan relasi sosialnya.

Anak dengan indikasi borderline pada umumnya tidak memiliki keterampilan untuk bersosialisasi. Hal ini dikarenakan kognitif anak borderline yang terbatas sehingga anak tidak mampu mengerti hal yang abstrak dan harus mengikuti instruksi. Schloss (Ghazala, 2012) mengatakan bahwa anak dengan indikasi borderline lebih suka menghindar dari keramaian, kurang mampu dengan kegiatan yang melibatkan kemampuan intelektual, ketergantungan hidup pada keluarga, kurang mengatasi rasa emosional ketika mereka marah ataupun emosional rasa senang yang berlebihan, dan memiliki rasa takut yang berlebihan, sehingga membuat mereka rentan mendapatkan beberapa masalah psikososial. Mereka kurang menguasai keterampilan sosial.

Cook (Siboro, 2007) menyatakan keterampilan sosial harus memiliki kelima aspek, yaitu (1) memperkenalkan diri (2) memulai percakapan (3) menjadi pendengar yang baik (4) memberikan pujian dan (5) memperlihatkan empati. Desvi (2005) menyatakan bahwa anak borderline sangat sulit bersosialisasi dengan lingkungannya. Anak borderline sangat emosional, cuek dan tidak peduli dengan orang di sekitarnya. Saat diberikan sesuatu mereka jarang mengucapkan terima kasih, saat melakukan salah tidak pernah meminta maaf, dan ketika menyuruh orang lain untuk memenuhi keinginannya tidak pernah mengucapkan kata tolong. Hasil penelitian yang dilakukan oleh Roy (2012) menyatakan bahwa anak dengan indikasi borderline mampu mengerjakan materi pelajaran sekolah walaupun sangat lambat dan dengan dorongan motivasi guru. Namun, anak tidak bisa melakukan keterampilan sosial agar dapat menyesuaikan diri dengan lingkungannya. Dalam kesehariannya, keterampilan sosial sangat dibutuhkan untuk bersosialisasi dengan temantemannya.

Hasil observasi dan wawancara peneliti dengan guru di sekolah SLB C1 Lawang dan SLB C1 Untung Tuah Samarinda, kebanyakan anak borderline ditolak oleh masyarakat, tidak jarang mereka diolok oleh teman sebaya mereka yang normal. Hal ini karena penampilan 
dan tingkah lakunya semaunya sendiri, kurang peduli dengan orang lain, tidak bisa mengatur emosi. Mereka kurang bisa bersosialisasi dengan teman baru maupun teman dari berbeda kelas. Selain itu banyak orang tua yang merasa takut dan malu jika anaknya bergaul dengan lingkungannya dengan alasan anaknya tidak diterima di masyarakat karena kekurangannya. Observasi juga dilakukan peneliti di SLB River Kids Malang, beberapa anak kurang dapat berinteraksi sosial dengan lingkungan secara baik yang mengakibatkan mereka semua tidak pernah saling bertegur sapa, bekerja sama dan bermain bersama dengan teman sekelas. Hal ini sesuai dengan Soemantri (2006), yang menyatakan bahwa anak borderline memiliki kesulitan dalam berteman, sering ditolak oleh kelompok, terisolasi dalam sosial sehingga mereka sering direndahkan dan dijadikan bahan ejekan. Penolakan sering terjadi di lingkungan teman sebaya.

Dengan mempertimbangkan batas kemampuan yang dimiliki oleh anak borderline, maka penelitian ini berfokus pada satu aspek, yaitu keterampilan memperkenalan diri. Keterampilan memperkenalkan diri sangat penting untuk diajarkan pada anak kecil yang memiliki kebutuhan khusus seperti anak borderline, hal ini sebagai usaha untuk mengembangkan pemahaman akan diri sendiri (Cartledge, 1995).

Dalam keadaan di lapangan, anak borderline masih sulit untuk memperkenalkan diri seperti menyebutkan nama panjang, nama orang tua, nama saudara, dan alamat rumah. Keterampilan memperkenalkan diri sangat penting digunakan untuk mempertahankan relasi dalam lingkungan sosialnya. Keterampilan memperkenalkan diri sangat diperlukan karena saat anak menemui orang baru di lingkungannya anak harus mampu mengenal dirinya sendiri, alamat serta nama kedua orangtuanya.

Dalam pendekatan social learning, Bandura (Alwisol, 2011) menjelaskan bahwa anak mampu belajar sikap, keterampilan dan perilaku yang merupakan hasil dari pengamatan. Anak bisa saja mencontoh kegiatan yang dilakukan oleh keluarga dan orang-orang di lingkungan sekitarnya. Bandura (dalam Biederman, 1998) menyatakan bahwa anak lebih banyak belajar dari mengamati perilaku orang lain. Anak mempelajari respon baru dengan melihat respon orang lain. Anak akan belajar dengan melihat tingkah laku orang lain dan akan mengikuti tingkah laku tersebut di kemudian hari. Melalui contoh anak akan mengamati perilaku untuk menghasilkan perilaku baru. Saat anak diberikan perilaku yang sama berulang kali, dengan sendirinya anak akan mengikuti perilaku tersebut. Mencontoh hal yang negatif akan membawa anak pada sikap yang negatif. Fenomena yang diambil oleh peneliti dari Kompasiana 
Juli 2011, yang diakses pada 20 Juni 2013, diberitakan bahwa anak SD di Rembang memukuli temannya karena mengikuti adegan "Smack Down". Berita dari situs yang sama pada September 2007 menyebutkan bahwa anak SLB di Sumedang menendang dan berkelahi dengan teman dikelasnya karena ingin mengikuti figur jagoan di film "Kamen Rider". Kejadian ini dikarenakan anak tersebut setiap hari menonton film action tersebut.

Modelling merupakan bagian dari instruksi. Hal ini sesuai dengan pernyataan Malone dkk (2006), guru sebagai fasilitator yang mengajarkan keterampilan sosial seharusnya menggunakan prinsip-prinsip dasar pelatihan perilaku untuk mengajarkan keterampilan. Pertama, guru memberikan instruksi. Selama pemberian instruksi ini, guru memberikan informasi, memberitahu bagaimana melakukan sesuatu dan menyediakan contoh-contoh. Kedua, guru mengulang keterampilan tersebut seperti yang sudah dicontohkan kepada anak. Selanjutnya, anak perlu dibawa pada situasi yang sebenarnya untuk melatih keterampilan yang baru ini. Seperti kata John Dewey (dalam Biederman, 1999) kurikulum yang efektif adalah learning by doing. Metode yang cocok digunakan untuk pengajaran keterampilan hidup adalah bermain peran, observational learning dan cooperative learning. Penelitian yang dilakukan oleh Biederman (1999) menyatakan bahwa ada pengaruh dalam penggunaan video modelling dalam kegiatan presentasi di kelas. Saat melakukan kegiatan presentasi, guru menggunakan video yang sama dengan materi apa yang ingin diajarkan. Keterampilan memperkenalkan diri menggunakan metode modelling diharapkan dapat memberikan contoh tingkah laku yang dimana kemudian anak dapat mengobservasi dan menirukan tingkah laku tersebut. Ketika anak belum mampu menirukan dengan benar, anak akan diberikan instruksi soal dan mengulangi contoh tingkah laku. Setelah berhasil melakukan, anak akan diberikan pengukuhan berupa pujian.

Berdasarkan fenomena tersebut, rumusan permasalahan penelitian ini adalah adakah pengaruh strategi pembelajaran Modelling dalam meningkatkan keterampilan memperkenalkan diri anak borderline. Hal ini dikarenakan mengamati dan mencontoh merupakan kegiatan yang paling disukai oleh anak-anak daripada membaca teori atau mendengarkan penjelasan panjang dari guru, sehingga materi yang diajarkan dengan pengamatan lebih cepat dipraktikan oleh anak. Hipotesa penelitian ini adalah Modelling dapat meningkatkan keterampilan memperkenalkan diri anak Borderline. Penelitian ini diharapkan bermanfaat sebagai suatu masukan dan pengetahuan baru bagi orang tua yang 
memiliki anak borderline dan guru sekolah luar biasa yang mempunyai siswa borderline. Sehingga mereka bisa menerapkan Modelling positif pada siswa atau anak mereka dalam kehidupan sehari-hari, sehingga anak dapat dengan mudah mengerti dan menyerap pelajaran dengan baik.

\section{METODE PENELITIAN}

\section{Subjek Penelitian}

Pengambilan sampel dari penelitian dilakukan dengan cara nonrandom, purposive sampling. Purposive sampling adalah pemilihan sampel sesuai yang dikehendaki (Latipun, 2011). Subjek dari penelitian ini adalah siswa kelas 5 SDLB Ruhui Rahayu Samarinda dengan minimal usia 10 tahun dan maksimal usia 15 tahun. Subjek memiliki nilai intelegensi quotient (IQ) 69 - 79 yang didapatkan berdasarkan hasil pengetesan dari dokumentasi pihak sekolah. Jumlah subjek yang dipakai adalah lima orang.

\section{Rancangan Penelitian}

Peneliti menggunakan Eksplanasi eksperimen, artinya mengutamakan cara - cara untuk memanipulasi objek penelitian sedemikian rupa sesuai dengan format penelitian yang diinginkan (Latipun, 2011). Pada penelitian ini rancangan yang digunakan adalah desain One-Group PretestPosttest Design. Simbol dari desain ini adalah :

\section{Pengukuran Pre-Test (O1) $\rightarrow$ Perlakuan Intervensi $(\mathrm{X}) \rightarrow$ Pengukuran Post Test $(\mathrm{O} 2)$}

\section{Gambar 1. Simbol Desain Eksperimen}

Desain eksperimen ini dilakukan dengan pretest sebelum perlakuan diberikan dan posttest sesudah perlakuan (Kazdin, 1991). Pada awal penelitian dilakukan pengukuran sebelum dilakukan manipulasi kemudian setelah diberikan manipulasi kembali dilakukan pengukuran (Seniati, 2011). Pada awal penelitian dilakukan pengukuran terhadap keterampilan memperkenalkan diri subjek, kemudian diberikan treatment berupa Modelling.

Penentuan anggota sampel dipilih berdasarkan kelompok-kelompok yang sudah tersedia, misalnya kelompok kelas yang dipilih berdasarkan perkiraan eksperimenter Subjek yang dipilih oleh peneliti membaur menjadi satu dengan teman sekelasnya. Pada saat perlakuan, semua subjek mendapatkan perlakuan yang sama dari peneliti. Penelitian ini menggunakan desain within-subject untuk mengontrol kondisi dan mendapatkan setting yang natural di dalam kelas. Hal ini dilakukan karena peneliti ingin fokus memberikan 
perlakuan terhadap 5 subjek yang merupakan siswa borderline yang berada dikelas. Sedangkan siswa lainnya yang berada di kelas memiliki nilai intelegensi dibawah 69.

\section{Metode Pengambilan Data}

Metode yang digunakan dalam pengumpulan data adalah dengan menggunakan metode dokumentasi, yaitu dokumen tertulis berupa data diri siswa dan hasil pengetesan intelegensi dari pihak instansi sekolah untuk mengetahui nilai intelegensi anak yang memenuhi kriteria dalam intelegensi borderline, yaitu nilai intelegensi 69 - 79 dengan maksimal waktu pengetesan tidak lebih dari 1 tahun. Peneliti melakukan observasi dan wawancara sebagai data perilaku keterampilan memperkenalkan diri subjek dan melakukan pencatatan tentang hal-hal yang berpengaruh dalam jalannya proses penelitian. Peneliti melakukan wawancara kepada guru sebagai informasi memperkenalkan diri tiap subjek sebelum dan sesudah diberikan perlakuan.

Peneliti juga menggunakan skala untuk mengukur keadaan awal subjek. Guru sekolah dan peneliti masing-masing mengisi skala dengan satu subjek secara bersamaan dan memberikan nilai sesuai keadaan subjek. Tujuan dari pemberian penilaian dari dua orang adalah agar mendapatkan hasil yang objektif. Peneliti memberikan perjanjian untuk penilaian pengisian skala pada guru agar memiliki persamaan kriteria penilaian. Skala yang dilakukan dalam penelitian berisi kemampuan memperkenalkan diri yang akan diajarkan pada anak. Item-item yang diberikan berdasarkan teori Catherine Mouris dalam program bantuan pertanyaan sosial pada anak retardasi mental ringan (Siboro, 2007). Skala berisi tiga bagian yaitu (a) data anak sebanyak 8 item yaitu nama panjang, nama panggilan, jenis kelamin, tempat lahir, tanggal bulan dan tahun lahir, alamat rumah dan nomer telepon. (b) data keluarga sebanyak 6 item yaitu nama ayah dan ibu, nomer hp ayah atau ibu, pekerjaan ayah dan ibu, dan nama saudara kandung dan (c) data sekolah sebanyak 5 item yaitu nama sekolah, kelas, alamat sekolah, nama guru kelas dan 2 nama teman sekelas. Seluruh bagian berjumlah 19 item. Dalam penyajian skala diberikan tiga pilihan yaitu jika anak tidak bisa menjawab ataupun diam diberi skor 0 , anak menjawab namun tidak tepat diberi skor 1 dan dapat menjawab dengan tepat diberi skor 2. Semakin tinggi skor yang diperoleh maka semakin menunjukkan kemampuannya dalam memperkenalkan diri.

\section{Prosedur Penelitian}

Pertama-tama peneliti melakukan survey untuk menentukan tempat penelitian yang cocok dengan kriteria penelitian. Setelah mendapatkan 
persetujuan dan mempersiapkan surat penelitian, peneliti melakukan wawancara dan observasi dengan guru kelas untuk menetukan subjek penelitian.

Kegiatan selanjutnya adalah melakukan asesmen awal untuk mengumpulkan dokumentasi data tentang hasil tes IQ subyek. Setelah itu dilanjutkan observasi untuk mengambil data pretest. Pengambilan data tersebut dilakukan oleh peneliti dan guru untuk menghindari subyektifitas dalam memberikan penilaian .

Kegiatan berikutnya dilanjutkan dengan pemberian intervensi berupa modeling dalam empat sesi kegiatan. Kelima subjek mendapatkan perlakuan secara bersamaan didalam kelas. Setiap sesi kegiatan diberi jeda 2 sampai 3 hari. Setelah kegiatan intervensi dalam empat sesi kegiatan selesai dilaksanakan peneliti dan guru melakukan pengambilan data posttest.

Adapun kegiatan intervensi adalah sebagai berikut :

1. Pembentukan rapport dilakukan selama 2 hari, di hari pertama peneliti melakukan pendekatan secara personal dengan subjek satu persatu. Dihari kedua peneliti mengumpulkan subjek di dalam kelas dan memutarkan video ice breaking.

2. Pemberian materi pertama tentang data diri dilakukan selama 2 hari dengan durasi 60 menit perhari.
Materi diberikan dalam bentuk visual berupa video animasi tentang cara memperkenalkan diri dengan menyebutkan nama lengkap, nama panggilan, jenis kelamin, tempat dan tanggal lahir, usia dan alamat. Video tersebut diputar 2 kali lalu setiap subyek diminta untuk melakukan praktek perkenalan diri sesuai dengan contoh dari video tersebut. Setelah itu peneliti meminta subjek mengerjakan soal tentang materi seperti nama lengkap, nama panggilan, jenis kelamin, tempat tanggal lahir. Subjek mempraktikkan kembali di depan kelas dengan bantuan peneliti saat subjek tidak bisa mengikuti.

3. Pemberian materi kedua tentang data keluarga : nama ayah, nama ibu, pekerjaan ayah, pekerjaan ibu, anak ke dari jumlah saudara, nama saudara. Sebelum memutar video, peneliti mengulangi materi kegiatan tentang data diri. Kemudian memutar video animasi tentang data keluarga sebanyak 2 kali lalu setiap subyek diminta untuk melakukan praktek perkenalan diri sesuai dengan contoh dari video tersebut. Setelah itu peneliti meminta subjek mengerjakan soal tentang materi dan mempraktekan kembali didepan kelas dengan bantuan peneliti saat subjek tidak bisa mengikuti.

4. Pemberian materi ketiga tentang data sekolah : nama sekolah, alamat sekolah, kelas, nama guru, nama 
teman sekelas. Sebelum memutar video, peneliti mengulangi materi kegiatan tentang data diri dan data keluarga. Kemudian memutar video animasi tentang data sekolah sebanyak 2 kali lalu setiap subyek diminta untuk melakukan praktek perkenalan diri sesuai dengan contoh dari video tersebut. Setelah itu peneliti meminta subjek mengerjakan soal tentang materi dan mempraktekan kembali didepan kelas dengan bantuan peneliti saat subjek tidak bisa mengikuti.

\section{Metode Analisa Data}

Metode analisa data yang digunakan dalam penelitian ini adalah teknik uji non parametrik dengan menggunakan teknik uji Wilcoxon Signed Ranks Test untuk mengetahui perbedaan signifikansi antara skor pretest dan posttest. Dalam hal ini peneliti menggunakan signifikansi $1 \%$, karena jumlah subjek yang terbatas hanya 5 subjek. Selain itu dalam penelitian juga menggunakan teknik uji Mann-Whitney Test untuk mengetahui perbandingan nilai pretest dan posttest antara guru dan peneliti.

\section{HASIL PENELITIAN}

\section{Deskripsi Data}

Hasil pengambilan data dideskripsikan sebagai berikut:

Tabel 1. Identitas Subjek

\begin{tabular}{ccccc}
\hline Nama & $\begin{array}{c}\text { Jenis } \\
\text { Kelamin }\end{array}$ & Kelas & Usia & IQ \\
\hline KA & Laki-laki & 5 & 10 Tahun 7 Bulan & 69 \\
AT & Laki-laki & 5 & 11 Tahun 3 Bulan & 75 \\
RH & Laki-laki & 5 & 10 Tahun 11 Bulan & 71 \\
EYG & Laki-laki & 5 & 10 Tahun 11 Bulan & 73 \\
EYG & Laki-laki & 5 & 10 Tahun 11 Bulan & 78 \\
\hline
\end{tabular}

Berikut rata-rata nilai keterampilan memperkenalkan diri berdasarkan data tiga kali prates dan tiga kali pascates pada skala perkenalan diri yang didapat dari kelima subjek: 
Tabel 2. Rata-Rata Nilai Pratest dan Pascates Subjek

\begin{tabular}{cccccc}
\hline Peneliti & $\begin{array}{c}\text { Pretes } \\
\mathbf{t}\end{array}$ & $\begin{array}{c}\text { Posttes } \\
\mathbf{t}\end{array}$ & Guru & Pretest & Posttest \\
\hline & 18.00 & 28.33 & & 19.00 & 30.33 \\
& 18.33 & 31.33 & & 18.67 & 32.33 \\
& 16.00 & 29.00 & & 16.33 & 30.33 \\
& 17.33 & 28.33 & & 18.33 & 30.00 \\
& 19.33 & 34.00 & & 19.33 & 34.00 \\
\hline Rata - rata & 17.80 & 30.20 & Rata - Rata & 18.33 & 31.40 \\
\hline
\end{tabular}

Dari tabel diatas, kelima subjek jelasnya ditunjukan pada grafik dibawah menunjukan nilai pascates yang lebih ini: tinggi daripada nilai prates, untuk lebih

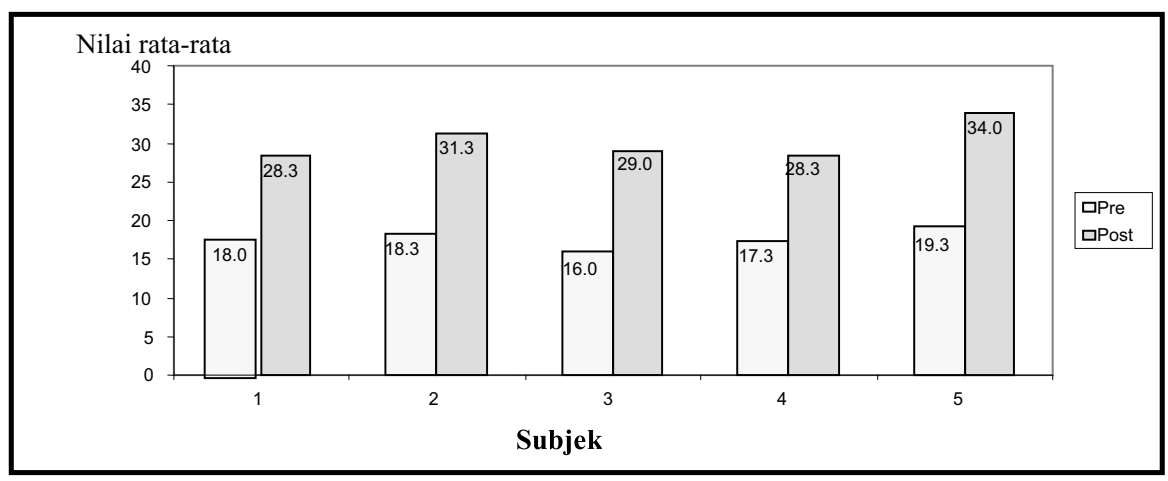

Gambar 3. Grafik Perbandingan Antara Nilai Rata-Rata Pretest dan Posttest Hasil Penilaian Peneliti

Berdasarkan grafik diatas, dapat borderline, menunjukan nilai yang lebih diketahui bahwa skor rata-rata pada saat tinggi daripada skor rata-rata pada saat pascates dari hasil penilaian pada anak prates pada kelima subjek yang diamati. 


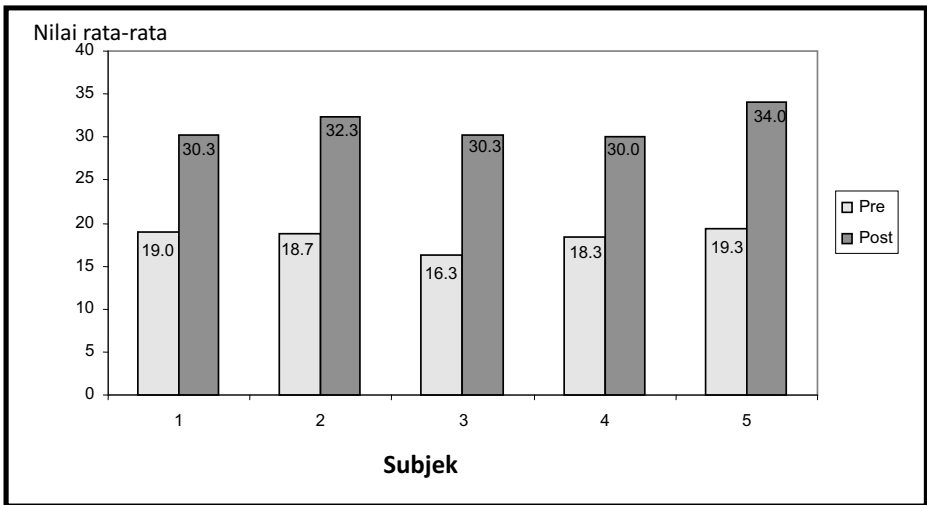

Gambar 4. Grafik Perbandingan Antara Nilai Rata-Rata Pretest dan Posttest Hasil Penilaian Guru

Demikian pula perbandingan skor rata-rata pada skor pretest dan posttest dari hasil penilaian oleh guru terhadap kelima subjek anak borderline menunjukan bahwa skor posttest lebih tinggi daripada skor rata-rata pretest pada kelima subjek yang diamati.

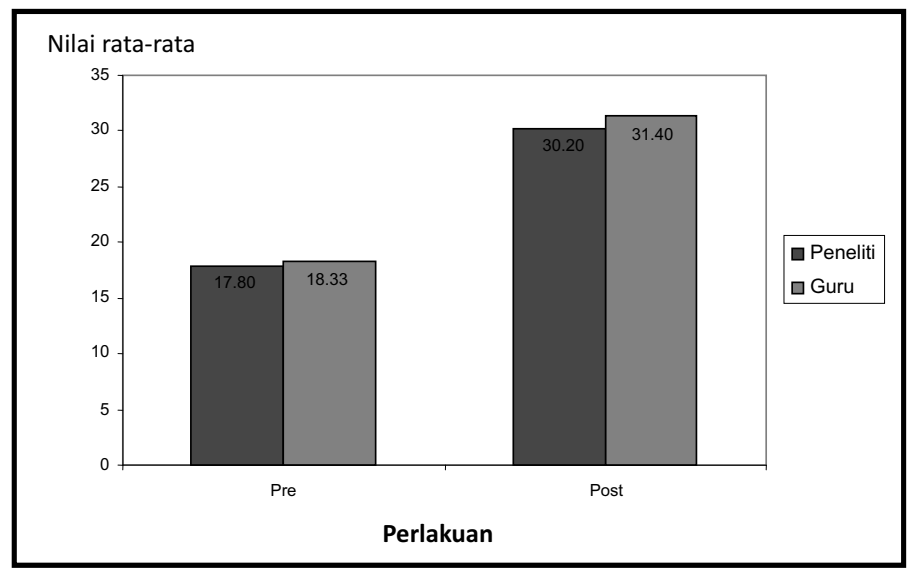

Gambar 5. Grafik Perbandingan Rata-Rata Nilai antara pretest dan posttest

Berdasarkan grafik di atas dapat diketahui bahwa antara penilaian guru dengan peneliti baik pada saat pretest maupun pada saat posttest tidak menunjukkan adanya perbedaan yang signifikan, karena dari nilai rata-rata yang diberikan kepada subjek hanya terdapat sedikit perbedaan.

Dari hasil penelitian, peneliti menggunakan perhitungan statistik dengan menggunakan Wilcoxon Signed Ranks Test untuk mengetahui perbedaan 
signifikan antara skor pretest dan posttest. Dalam hal ini peneliti menggunakan signifikansi $1 \%$.

\section{Hasil Uji Hipotesis}

Hasil Analisa Wilcoxon Signed Ranks Test

Tabel 3. Perbedaan Penilaian Pretest dan Posttest Antara Guru dan Peneliti

\begin{tabular}{ccccc}
\hline N & Mean Ranks & Sum of Ranks & & Post - Pre \\
\hline 3 & \multirow{2}{*}{15.50} & 465.00 & $\mathrm{Z}$ & -4.818 \\
\cline { 3 - 4 } 0 & & & $\mathrm{P}$ & 0.000 \\
\hline
\end{tabular}

Dari hasil Wilcoxon Signed Ranks Test secara keseluruhan yang dinilai oleh peneliti dan guru diperoleh $(p=0,000)$. Hasil penilaian secara bersamaan antara guru dan peneliti berbeda signifikan, karena pada awal kegiatan peneliti membuat perjanjian dengan guru tentang kesepakatan terkait standar dan proses penilaian. Subjek diberi waktu 10 detik untuk menjawab soal, ketika melebihi batas waktu subjek diberi nilai 0 walaupun dapat menjawab dengan benar.
Sedangkan perbandingan antara nilai pretest dan posttest pada hasil penilaian guru sendiri, ternyata memang menunjukkan adanya perbedaan yang cukup besar, dimana nilai pretest nilai rata-ratanya sebesar 18.33 , dan pada saat posttest meningkat menjadi 31.40 . Hal ini juga terjadi pada perbandingan antara nilai pretest dan posttest pada hasil penilaian peneliti sendiri, yang juga menunjukkan adanya perbedaan yang cukup besar, dimana nilai pretest nilai rata-ratanya sebesar 17.80 , dan pada saat posttest meningkat menjadi 30.20.

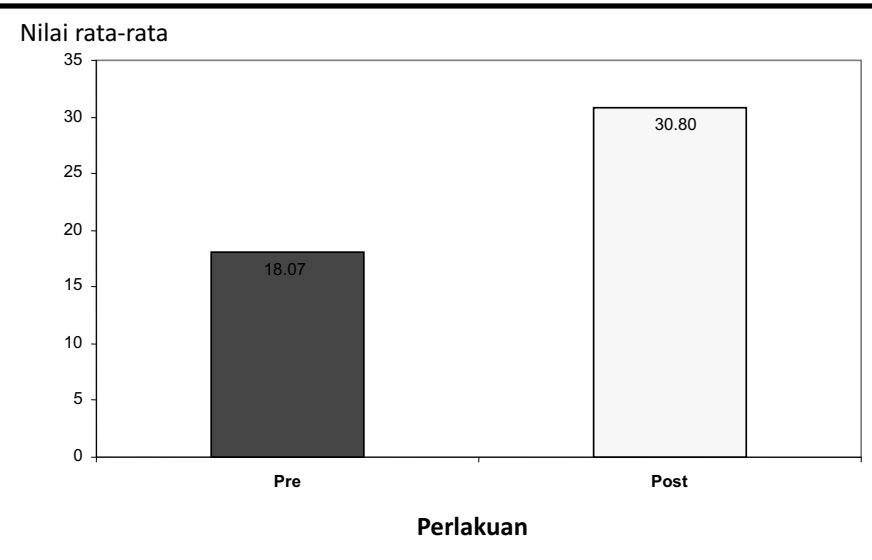

Gambar 6. Perbandingan Rata-Rata Nilai Antara Pretest dan Posttest Secara Keseluruhan 
Secara keseluruhan dari penilaian yang telah dilakukan oleh peneliti maupun guru, dapat diketahui bahwa nilai pada saat pretest sebesar 18.07 menunjukkan adanya perbedaan yang besar jika dibandingkan dengan nilai pada saat posttest yaitu sebesar 30.80. Hal ini dapat diartikan bahwa adanya pemberian perlakuan Modelling melalui media video tersebut memang mampu meningkatkan kemampuan keterampilan memperkenalkan diri anak Borderline secara nyata. Karena anak yang pada awalnya hanya menguasai beberapa materi dasar seperti nama, alamat dan sekolah mampu menyebutkan materi lain yang sesuai dengan skala perkenalan diri dengan benar setelah menonton video berulang kali dan melihat contoh dari peneliti.

Peneliti juga menggunakan MannWhitney Test untuk mengetahui perbandingan nilai pretest dan posttest antara guru dan peneliti. Hal ini ditunjukan dalam tabel berikut:

Tabel 4. Perbandingan Nilai Pretest dan Posttest Gabungan Guru dan Peneliti

\begin{tabular}{ccc}
\hline & Pre & Post \\
Mann-Whitney U & 95.50 & 112.50 \\
Wilcoxon W & 215.50 & 232.50 \\
Z & -0.724 & 0.000 \\
P & 0.486 & 1.000 \\
\hline
\end{tabular}

Dari hasil Mann-Whitney Test menunjukan adanya perbedaan nilai dari penilaian antara pretest dan posttest yang dilakukan oleh peneliti dan guru. Hal ini menunjukan bahwa ada perubahan nilai keterampilan memperkenalkan diri anak borderline setelah mendapat perlakuan berupa modelling.

\section{PEMBAHASAN}

Hasil penelitian menunjukkan bahwa keterampilan memperkenalkan diri subjek meningkat setelah mendapat perlakuan berupa modeling. Hal ini ditunjukan dengan nilai posttest 30,80 yang lebih baik dibandingkan nilai pretest 18,07 . Hasil penelitian tersebut selaras dengan hasil penelitian terdahulu yang membuktikan bahwa untuk meningkatkan keterampilan sosial anak retardasi mental ringan diperlukan adanya pelatihan dengan cara penggunaan video atau kegiatan pelatihan yang dilakukan berulang kali (Rehfeld, 2004; Hanafi, 2003). Penelitian-penelitian terdahulu dilakukan dalam konteks peningkatan keterampilan sosial anak tunagrahita ringan dengan kelompok sekolah menengah pertama melalui pelatihan keterampilan sosial dan penggunaan video modelling untuk peningkatan keterampilan dasar sosial pada anak retardasi mental sedang. Berbeda dengan penelitian ini yang menggunakan subjek penelitian anak borderline dari 
kelompok usia sekolah dasar.

Berdasarkan keadaan di lapangan pada saat penelitian ditemukan bahwa anak borderline harus berulang kali mengerjakan materi pelajaran yang diberikan oleh guru. Mereka cenderung susah untuk dekat dengan orang yang baru ditemuinya. Saat peneliti menanyakan siapa namanya, mereka lambat dan ragu-ragu untuk menjawab. Saat istirahat mereka hanya mau bermain dengan teman sekelasnya. Hal ini sesuai dengan Cartladge dkk (1995) yang menunjukan bahwa anak-anak yang mengalami gangguan retardasi mental memiliki keterampilan sosial rendah, mereka cenderung menunjukkan prasangka permusuhan saat berhadapan dengan stimulus sosial yang ambigu dan mereka sering mengartikannya sebagai tindakan agresif. Berdasarkan penelitian Daniel Goleman (dalam Wallin dan Durr, 2002) juga menegaskan bahwa anak perlu belajar mengatur perasaannya dan mengembangkan keterampilan sosial untuk meraih prestasi tidak hanya dalam lingkungan akademis namun juga dalam lingkungan yang lebih luas.

Keterampilan memperkenalkan diri pada penelitian ini menggunakan teknik modeling yang dilakukan dengan instruksi yang berulang, yaitu peneliti memperlihatkan materi pada subjek dalam bentuk video, kemudian subjek maju ke depan kelas untuk mempraktikan. Saat subjek tidak bisa menjawab, peneliti memberikan tugas pada subjek tentang materi, kemudian subjek diminta maju ke depan kelas untuk kedua kalinya. Setelah subjek berhasil menirukan dengan benar maka peneliti memberikan pujian. Hal ini sesuai dengan pendapat Bandura (1971), modelling adalah kegiatan memberikan contoh tingkah laku yang diharapkan kemudian anak mengobservasi dan menirukan tingkah laku tersebut apabila anak berhasil menirukan tingkah laku tersebut akan diberikan pengukuhan yang positif.

Peningkatan penguasaan materi memperkenalkan diri pada kelima subjek diduga dipengaruhi oleh nilai intelegensi. Sebab hal ini tidak diteliti lebih lanjut oleh peneliti. Hal ini menjadi salah satu confounding factor (faktorfaktor yang rancu) dalam penelitian ini. Terlihat dari subjek lima yang memiliki nilai intelegensi paling tinggi dari subjek lainnya dapat menjawab semua materi dengan benar dan peneliti hanya sedikit memberikan bantuan, berbeda dengan subjek lainnya yang masih salah dalam menjawab materi. Selain itu dipengaruhi pula oleh orang tua dan subjek itu sendiri. Subjek 5 dan subjek 2 lebih kooperatif bila dibandingkan subjek 1, 3 dan 4. Hal ini menunjukan bahwa anak borderline memiliki keinginan untuk dapat diterima di lingkungannya. Subjek 5 dan 2 selalu bertanya dan menanyakan apakah subjek salah dalam menjawab. Hal ini didukung oleh pendapat Hurlock (2005), yang menyatakan anak dalam 
masa kanak-kanak akhir memiliki keinginan untuk diterima di lingkungannya.

Saat pertama kali intervensi berlangsung, kelima subjek terlihat tidak percaya diri dan malu untuk maju ke depan kelas. Peneliti melakukan pendekatan pada kelima subjek tersebut dengan memutarkan video terlebih dahulu dan menggunakan video perkenalan diri sebagai materi dari modeling. Setelah beberapa kali pertemuan dilakukan setiap hari, kelima subjek mampu maju ke depan kelas saat namanya disebutkan tanpa harus dibujuk terlebih dahulu. Subjek-subyek tersebut lebih mudah mengerjakan tugas yang diberikan setelah menonton contoh dari video perkenalan diri. Hal ini dikemukakan oleh Bellack dan Harsen (dalam Malone, 2006) mengartikan keterampilan sosial sebagai kemampuan individu untuk mengungkapkan perasaannya baik positif maupun negatif dalam konteks hubungan interpersonal yang memiliki kemampuan untuk mengungkap respon baik verbal maupun nonverbal. Untuk dapat mengembangkan keterampilan sosial, anak harus dapat menyesuaikan diri dengan tuntutan sosial agar dapat menjadi pribadi yang mampu hidup bermasyarakat. Penelitian ini juga didukung oleh Biederman (1999) yang telah membuktikan dari penelitian terdahulu bahwa penggunaan video modeling berpengaruh dalam pemberian materi pada saat kegiatan presentasi.

Dalam pelaksanaan perlakuan, materi perkenalan diri dimulai dengan menonton video sebanyak 3 kali dan mempraktekan materi di depan kelas. Masing-masing dari kelima subjek melakukan sendiri tanpa adanya bantuan. Saat salah satu subjek tidak bisa menjawab, peneliti memberikan soal pada subjek tersebut untuk dijawab, diberitahukan jawaban yang benar dan diberikan waktu untuk menghafal. Setelah itu subjek tersebut maju ke depan untuk mengulangi memperkenalkan diri. Peneliti memberi bantuan saat subjek mengalami kesulitan menyebutkan materi sampai subjek dapat menirukan dengan jawaban yang benar. Kelima subjek telah belajar tingkah laku baru dengan cara mengamati model (video dan peneliti) melalui efek-efek perbuatan sendiri. Dalam hal ini sesuai dengan pendapat Malone dkk (2006) yang berpendapat bahwa dalam pengajaran anak berkebutuhan khusus harus ada pengulangan dalam prinsip pelatihan dasar pengajaran keterampilan. Pengajar harus memberikan instruksi, kemudian mengulangi materi beberapa kali hingga anak mampu mengikuti instruksi, setelah itu anak dibawa dalam keadaan sebenarnya untuk dilatih keterampilan yang baru.

Anak borderline sepintas tidak memiliki perbedaan dengan anak lainnya. Akibatnya masyarakat tidak memberikan perhatian khusus (Triani, 
2013). Padahal anak borderline juga membutuhkan perhatian intensif dalam interaksi di lingkungannya. Dengan adanya pengajaran yang berulang dan rutin dapat mempermudah pemahaman anak borderline dan membuktikan bahwa mereka mampu memiliki keterampilan sosial untuk berinteraksi dengan lingkungannya. Modelling yang digunakan dalam penelitian ini, sesuai dengan pendapat Michelson (1985, dalam Siboro 2007), yaitu mengembangkan suatu prosedur kegiatan untuk melatih individu yang memiliki keterbatasan keterampilan sosial.

Pada penelitian ini terdapat beberapa kelemahan, yaitu penelitian skala menurut Azwar (2012), dapat mengakibatkan efek bawaan (carry over effects) apabila pada saat peneliti dan guru mengukur kemampuan memperkenalkan diri subyek, sikap subjek kurang bersungguh-sungguh, subjek dalam keadaan lelah, ketidaksiapan dalam pengisian, dan perubahan suasana hati. Banyaknya siswa di kelas dapat menyebabkan subjek menjadi tidak fokus dalam mengikuti kegiatan. Peneliti telah mengusahakan agar kelima subjek dipisahkan dari murid lainnya dan diberikan jadwal sendiri untuk kegiatan penelitian. Namun, pihak sekolah meminta peneliti agar mencampur subjek dan teman lainnya agar tidak ada kecemburuan sosial di dalam kelas.

\section{PENUTUP}

\section{Simpulan}

Berdasarkan hasil penelitian dan pembahasan di atas dapat disimpulkan bahwa adanya peningkatan keterampilan memperkenalkan diri anak borderline melalui modelling. Hal ini dapat dilihat dari adanya perbedaan nilai pretest dan posttest kelima subjek dengan rata-rata penilaian pretest 18.07 meningkat pada penilaian posttest 30.80 dengan perbandingan ( $p=0.486$ ) dan tidak ada perbedaan penilaian yang dilakukan oleh guru dan peneliti $(p=0,000)$.

\section{Saran}

1. Bagi siswa Borderline perlu mendapatkan pengajaran materi memperkenalkan diri dengan Modelling secara berulang-ulang dan terus menerus, agar anak tidak lupa dan mendapatkan hasil yang maksimal.

2. Untuk para guru, terapis dan tenaga pengajar lainnya dapat menggunakan materi Modelling memperkenalkan diri dalam materi dasar pembelajaran di kelas sejak kelas satu, dan terus diulang pada saat naik kelas selanjutnya.

\section{DAFTAR PUSTAKA}

Alwisol. (2011). Psikologi kepribadian. Malang: Universitas 
Muhammadiyah Malang Press

Azwar. (2012). Validitas dan reliabilitas. Yogyakarta : Pustaka Pelajar

Azwar. (2010). Pengantar psikologi intelegensi. Yogyakarta : Pustaka Pelajar

Bandura. (1971). Social learning theory. European journal of personality. Accesed on April, 202013 from www.Taylor \& Francise Online.org Biederman, G. B., Stepaniuk, S., Davey, V., Raven, K., and Ahn, D. (1999). Observational learning in children with down syndrome and developmental delays : The effects of persentation speed in videotaped modelling. Journal of down syndrome research and practice. $6,(1), 12-18$

Biederman, G.B, Fairhall, Davey, V., Raven, K., and Ahn, D. (1998). Teaching basic skill to children with down syndrome and developmental delays : The relative Efficacy of Interactive Modelling with Social Rewards of Benchmark achievements and passive observation. Journal of down syndrome research and practice. $5,(1), 23-33$

Cartledge, G. and Milburn, J. F. (1995). Teaching social skill to children and youth. Massachusetts :
Needham Heights

Delphie, B. (2006). Pembelajaran anak tunagrahita. Bandung : Refika Aditama

Desvie, Y. (2005). Keterampilan sosial anak yang mengalami gangguan perilaku. Laporan Penelitian, Program Studi Magister Psikologi Fakultas Kedokteran Universitas Sumatera Utara, Medan

Efendi. ( 2006 ). Pengantar psikopedagonik anak berkelainan. Jakarta : Bumi Aksara

Engel, A. (1994). The challenge of slow learning child, Journal of educational leadership, 151 - 155

Ezell, H., Goldstein, H. (1991). Observational learning of comprehension monitoring skills in children who exhibit mental retardation. Journal of speech and hearing research, 34, 141-154

Gabbe. (2008). Gejala arsitektur sekolah Edisi 3. Fakultas Teknik Universitas Indonesia, Jakarata

Ghazala, Rubina \& Malik. (2012). Pengaruh intervensi akademik pada pengembangan keterampilan pembelajaran lambat : Pakistan jurnal penelitian psikologis, 27,(1), $135-151$ 
Gumpel, T. (1994). Social competence and social skills training for persons with mental retardation: An expansion of a behavioral paradigm. Education and training in mental retardation,29(3),194201 Accesed on June, 192013 frow www.eric.ed.gov

Hanafi. (2003). Pelatihan keterampilan sosial anak tunagrahita usia 13-18 tahun di balai besar rehabilitas sosial bina grahita kartini Temanggung. Thesis, Program Pascasarjana Universitas Gajah Mada, Yogyakarta

Hamalik, O. (2010). Psikologi belajar mengajar. Bandung : Sinar Baru Algesindo

Hurlock, E. H. (1972). Child development fifth edition. United States of American : McGraw-Hill Book Company

Hurlock, E. H. (2005). Perkembangan anak jilid 1. Jakarta : Erlangga

Kazdin, A. (1991). Research design in clinical psychology. USA : General Psychology Series

Latipun. (2011). Psikologi eksperimen. Malang : Universitas Muhammadiyah Malang Press

Linn, K. B. (1984). The effects of social skill and peer involvements on the social adjustment of preadolescents. Journal of child developments. 55, (1), 151-162

Malone, H., Sigafoos, J., O'Reilly, M., de La Cruz, Edrichinsa, S., and Lancioni, G. (2006). Comparing video prompting to video modelling for teaching daily living skill to six adults with developmental disabilities. Journal of educational and training in developmental disabilities, 41, (4), 344-356

Matson., Andrasik., Milan, M., L'Abate, L. (1985) Social skills training for the mentally retarded. Handbook of social skills training and research. United States of America : John Willey \& Sons, Inc

Muller, R. (2008). Doing psychiatric wrong : A critical and prescriptive look at a faltering profession. New York, London : The Analitic Press

Ollendick, Thomas \& Oswald, Donnald. (1989). Role-play taking and sosial competence in autism and mental retardation. Journal of autism and development disorders, No 1, Vol 19 : Virginia Polytechnic Institute and State University

Olorunda, E., Tolu. (2010) Efficacy of modelling and shaping strategies on attitude of children with mild 
mental retardation towards reading in Ibadan, Nigeria. European journal of social sciences. 16, (4), 645-656

Purwanta, E. (2012). Modifikasi perilaku alternatif penanganan anak berkebutuhan khusus. Yogyakarta: Pustaka Media

Ramdhani, N. (2001). Pelatihan keterampilan sosial untuk terapi kesulitan bergaul. Thesis, Program Studi Pasca Sarjana Psikologi Universitas Gajah Mada, Yogyakarta

Rehfeldt, Melissa, \& Bidwell. (2004). Using video modelling to teach a domestic skill with an embedded social skill to children with severe mental retardation. Journal of behavioral intervention. 19, 263274. Accesed on June, 192013 from www.interscience.wiley.com

Roy, B. (2012). Adjustments problems of educable mentally retarded. International Journals of scientific and research publications. Accesed on February, 252013 from www.ijsrp.org

Seniati, Yulianto \& Setiadi. (2011). Psikologi eksperimen. Jakarta : Indeks

Siboro, N. (2007). Pelatihan memperkenalkan diri pada anak retardasi mental ringan di $S \angle B$ Negeri Semarang. Thesis, Program Magister Profesi Psikologi Universitas Katolik Soegijapranata, Semarang

SLB Sumedang ricuh karena aksi Kamen Rider. Harian Online Kompasiana. 17 September 2007. Diakses 20 J u n i 2013 , http:/kompasiana.com/metro/inde x.htm

Soemantri, S. (2006). Psikologi anak luar Biasa. Bandung : Refika Aditama

Teman sekelas babak belur karena "Smack Down". Harian Online Kompasiana. 07 Juli 2011. Diakses 20 J u n i 2013 , http:/kompasiana.com/metro/inde x.htm

Triani, N \& Amir. (2013). Pendidikan anak berkebutuhan khusus lamban belajar slow learner. Jakarta : Luxima Metro Media

Wallin, K \& Durr, M. (2002). Creativity and expresive arts in social emotional learning. Journal of reclaming children and youth. 11, 30 